\title{
ESTIMASI ASUPAN KAROTENOID PADA USIA DEWASA DI INDONESIA
}

\author{
(Estimation of carotenoid intake on Indonesian adult)
}

\author{
Linda Riski Sefrina ${ }^{1 *}$, Dodik Briawan ${ }^{1}$, Tiurma Sinaga ${ }^{1}$, Dewi Permaesih ${ }^{2}$ \\ ${ }^{1}$ Departemen Gizi Masyarakat, Fakultas Ekologi Manusia (FEMA), Institut Pertanian Bogor, Bogor 16680 \\ ${ }^{2}$ Pusat Penelitian dan Pengembangan Upaya Kesehatan Masyarakat Balitbangkes Kemenkes RI, Bogor \\ 16117
}

\begin{abstract}
The objective of this study was to estimate carotenoid intake of Indonesian adults. A cross-sectional study design was used in this study. Secondary data was analyzed from the national consumption survey 2014 that was conducted by Research and Development Department of Indonesia Health Ministry. The number of subjects were 86,036. Assessment of food consumption used food recall 1x24 hour. Carotenoid content was obtained from the various references that have been matched to survey's food items. The total carotenoid intake was the sum of five carotenoid sub-classes ( $\alpha$-caroten, $\beta$-caroten, $\beta$-cryptoxanthine, lutein + zeaxanthine and lycopene). Median of total carotenoid intake was $551.62 \mu \mathrm{g} /$ day. Intake of total carotenoid was significantly difference by subject characteristics (gender, age, area, education level, job) and food groups consumption ( $p<0.05)$.
\end{abstract}

Keywords: adults, carotenoid, intake

\begin{abstract}
ABSTRAK
Tujuan penelitian ini adalah untuk melakukan estimasi asupan karotenoid pada usia dewasa di Indonesia. Penelitian ini menggunakan desain cross-sectional dengan data sekunder yang berasal dari survei konsumsi nasional 2014 oleh Badan Penelitian dan Pengembangan Kesehatan Kementerian Kesehatan Republik Indonesia. Jumlah subjek yang dianalisis sebesar 86.036 subjek. Survei konsumsi makanan menggunakan food recall 1×24 jam. Kandungan karotenoid diperoleh dari berbagai sumber yang telah disesuaikan dengan bahan pangan survei konsumsi. Asupan total karotenoid merupakan penjumlahan dari asupan lima subkelas karotenoid ( $\alpha$-karoten, $\beta$-karoten, $\beta$-kriptoxantin, lutein+zeaxantin dan likopen). Median asupan total karotenoid subjek sebesar 551,62 $\mu \mathrm{g} /$ hari. Terdapat perbedaan signifikan asupan total karotenoid berdasarkan karakteristik subjek (jenis kelamin, golongan usia, klasifikasi daerah, status pendidikan, status pekerjaan) dan konsumsi kelompok pangan sumber karotenoid $(p<0,05)$.
\end{abstract}

Kata kunci: asupan, dewasa, karotenoid

\section{PENDAHULUAN}

Penyakit Tidak Menular (PTM) merupakan penyebab kematian terbesar pada angka kematian dunia. Sebesar 66\% kematian akibat PTM terjadi di dunia, dengan angka kematian mencapai 38 juta jiwa setiap tahunnya (WHO 2014). Disamping itu, PTM merupakan penyakit yang menyebabkan 71\% kematian di Indonesia (WHO 2014). Prevalensi PTM di Indonesia dari tahun 2007 ke
2013 mengalami peningkatan antara lain penyakit diabetes melitus (DM) dari $1,1 \%$ menjadi $1,5 \%$, hipertensi dari $7,6 \%$ menjadi $9,4 \%$, dan stroke dari 6,0\% menjadi 7,0\%o. Prevalensi tertinggi menurut usia berdasarkan jenis PTM antara lain kanker pada usia $>75$ tahun, DM pada usia 55-64 tahun, hipertensi pada usia $>75$ tahun, PJK (Penyakit Jantung Koroner) pada usia $>65$ 74 tahun dan stroke pada usia $>75$ tahun (Balitbangkes 2013).

"Korespondensi: Telp: +6285727172915, Surel: lindariski@gmail.com 
Penelitian klinis maupun epidemiologi telah menemukan adanya peran radikal bebas dan oksidan terhadap perkembangan PTM (Maiani et al. 2009). Radikal bebas secara normal diproduksi oleh tubuh. Radikal bebas yang terbentuk dapat dinetralisir oleh antioksidan. Timbulnya PTM menunjukkan adanya ketidakseimbangan antara radikal bebas dan antioksidan (Pham-Huy et al. 2008).

Pencegahan PTM dapat dilakukan melalui perubahan perilaku, salah satunya yaitu meningkatkan konsumsi sayur dan buah (Boeing et al. 2012). Karotenoid merupakan antioksidan yang paling banyak ditemukan dalam plasma darah manusia. Karotenoid banyak terdapat dalam sayur dan buah. Karotenoid merupakan antioksidan yang berfungsi sebagai radical scavenging antioxidant atau antioksidan yang berfungsi mencari dan melawan radikal bebas, terutama singlet oksigen (Maiani et al. 2009). Asupan karotenoid mampu menurunkan risiko DM 16\% (Sluijs et al. 2015). Penelitian Helmizar et al. (2010) di Padang menunjukkan estimasi asupan $\beta$-karoten sebesar $15.000 \pm 6.700 \mu \mathrm{g} / \mathrm{hari}$.

Selama ini belum terdapat penelitian di Indonesia yang menilai asupan karotenoid dengan skala data nasional. Oleh karena itu, tujuan dari penelitian ini meliputi (1) menganalisis konsumsi pangan sumber karotenoid; (2) mengestimasi asupan karotenoid pada usia dewasa di Indonesia; dan (3) mengetahui perbedaan asupan karotenoid berdasarkan karakteristik subjek dan konsumsi pangan sumber karotenoid.

\section{METODE}

\section{Desain, tempat, dan waktu}

Desain penelitian yang digunakan adalah cross-sectional. Penelitian estimasi asupan karotenoid dilakukan di Departemen Gizi Masyarakat, Fakultas Ekologi Manusia, Institut Pertanian Bogor, pada bulan Mei - Agustus 2016.

\section{Jenis dan cara pengumpulan data}

Sumber data yang digunakan adalah data sekunder, yang berasal dari Survei Konsumsi Makanan Individu (SKMI) 2014. SKMI 2014 merupakan salah satu tahap dalam Studi Diet Total (SDT) 2014. Pengambilan data SKMI 2014 dilaksanakan di seluruh wilayah Indonesia oleh Badan Penelitian dan Pengembangan Kementerian Kesehatan Republik Indonesia (Balit- bangkes Kemenkes RI). Populasi dalam SKMI 2014 adalah semua Rumah Tangga (RT) yang mewakili seluruh estimasi provinsi di Indonesia. Teknik pengambilan subjek SKMI 2014 menggunakan teknik two-stage stratified sampling (Balitbangkes 2014). Total subjek teranalisis berasal dari semua golongan usia dalam penelitian SKMI 2014 sebesar 143.360 anggota rumah tangga (ART). Subjek penelitian merupakan ART teranalisis dan sudah melalui tahap cleaning dan imputasi (nilai energi $<1 / 3$ Angka Kecukupan Energi (AKE) atau $>1$ 2/3 AKE dan energi $<500$ Kkal) dari Laboratorium Manajemen Data Balitbangkes Kemenkes RI yaitu sebesar 91.984 subjek. Kriteria inklusi untuk penelitian ini adalah berusia $\geq 19$ tahun, termasuk dalam kondisi biologis "sehat" (Kuesioner SKMI Individu Blok VIII baris 5). Total subjek yang dianalisis adalah 86.036 subjek dan berasal dari 33 provinsi di Indonesia.

Data karakteristik subjek didapatkan dari Kuesioner SKMI 2014 RT, antara lain jenis kelamin pada B (Blok) IV K (Kolom) 4, usia dari BIV K10, klasifikasi daerah dari BI baris 5, status pendidikan dari BIV K11, dan status pekerjaan dari BIV K12.

Kandungan karotenoid didapatkan dari USDA National Nutrient Database for Standard Reference Release 28 tahun 2015, Tabel Komposisi Pangan Indonesia (TKPI), dan jurnal ilmiah lainnya. Apabila terdapat kadar karotenoid bahan pangan yang tidak diketahui maka diperkirakan dengan menggunakan data kadar karotenoid jenis bahan pangan yang memiliki kesamaan atau kemiripan. Pada database karotenoid telah memperhitungkan hampir semua cara pengolahan (USDA 2015). Sebanyak 748 bahan pangan mengandung karotenoid. Asupan total karotenoid merupakan penjumlahan dari asupan lima subkelas karotenoid ( $\alpha$-karoten, $\beta$-karoten, $\beta$-kriptoxantin, lutein+zeaxantin dan likopen).

\section{Pengolahan dan analisis data}

Hasil pengolahan data secara deskriptif menunjukkan data skewed positif dan tidak terdistribusi normal. Penyajian data konsumsi kelompok pangan dalam rata-rata (median) g/hari. Rata-rata tetap digunakan meskipun data tidak terdistribusi normal. Hal ini dikarenakan sebagian besar median konsumsi bernilai nol. Asupan karotenoid disajikan dalam median menurut kuartil asupan total karotenoid. Kuartil rendah (kuartil 
1 dan 2) dengan asupan total karotenoid berkisar antara 0,00-551,61 $\mu \mathrm{g} /$ hari. Kuartil tinggi terdiri atas kuartil 3 dan 4, dengan asupan total karotenoid berkisar antara 551,62-172.318,10 $\mu \mathrm{g} /$ hari. Uji komparatif digunakan untuk mengetahui perbedaan asupan total karotenoid berdasarkan karakteristik subjek. Uji Mann-Whitney digunakan untuk mengetahui perbedaan asupan total karotenoid berdasarkan jenis kelamin, klasifikasi daerah, status pendidikan dan status pekerjaan. Uji Kruskal-Walls post-hoc Mann-Whitney digunakan untuk mengetahui perbedaan asupan total karotenoid berdasarkan golongan usia.

\section{HASIL DAN PEMBAHASAN}

\section{Konsumsi sumber karotenoid}

Berdasarkan database yang digunakan dan data konsumsi yang diperoleh, kelompok pangan yang berkontribusi terhadap asupan total karote-noid diurutkan dari yang tertinggi adalah sayuran dan hasil olahannya $(68,0 \%)$, bumbu dan hasil olahannya $(10,0 \%)$, buah dan hasil olahannya $(9,0 \%)$, umbi-umbian dan hasil olahannya $(5,0 \%)$, kacang-kacangan dan biji $(4,0 \%)$ (Tabel 1). Hasil ini hampir sama dengan penelitian Puspita (2016), yang dilakukan pada 200 subjek usia 25-70 tahun di Bogor, menunjukkan sayuran dan olahannya merupakan kelompok pangan dengan kontribusi terbesar $(54,0 \%)$ pada asupan total karotenoid.

Tabel 1. Kontribusi kelompok pangan terhadap asupan total karotenoid pada usia dewasa di Indonesia

\begin{tabular}{lc}
\hline \multicolumn{1}{c}{ Kelompok pangan } & $\begin{array}{c}\text { Kontribusi terhadap } \\
\text { asupan total karotenoid }\end{array}$ \\
\hline $\begin{array}{l}\text { Sayuran dan } \\
\text { hasil olahannya }\end{array}$ & $68,0 \%$ \\
Bumbu dan olahan & $10,0 \%$ \\
$\begin{array}{l}\text { Buah dan hasil olahannya } \\
\text { Umbi-umbian dan hasil }\end{array}$ & $9,0 \%$ \\
olahannya & $5,0 \%$ \\
$\begin{array}{l}\text { Kacang-kacangan } \\
\text { dan biji }\end{array}$ & $4,0 \%$ \\
\hline
\end{tabular}

Bahan pangan yang paling berkontribusi pada asupan total karotenoid yang berasal dari kelompok umbi dan olahan adalah ubi jalar putih mentah, ubi jalar kuning mentah, dan ubi jalar merah mentah. Bahan pangan yang paling berkontribusi dari kelompok kacang, biji dan olahan adalah tahu mentah, biji melinjo mentah dan emping melinjo. Bahan pangan yang paling berkontribusi dari kelompok sayur dan olahan adalah bayam, wortel dan tomat merah. Bahan pangan yang paling berkontribusi dari kelompok buah dan olahan adalah semangka buah, pepaya, dan jambu biji. Bahan pangan yang paling berkontribusi dari kelompok bumbu dan olahan yaitu cabai rawit segar, cabai merah segar dan cabai merah kering.

Tabel 2 menunjukkan median konsumsi kelompok sayuran dan hasil olahannya $(55,9$ $\mathrm{g} /$ hari) merupakan median konsumsi tertinggi dibandingkan dengan kelompok pangan lain. Median konsumsi sumber karotenoid Indonesia ini jauh lebih rendah dibandingkan penelitian lain seperti di di Spanyol (sayuran 45,1; umbiumbian 70,1 g/hari; buah 285,3 g/hari) (Agudo et al. 2007).

Laki-laki mengonsumsi umbi-umbian dan hasil olahannya dan kacang-kacangan dan biji lebih besar dari perempuan $(\mathrm{p}<0,05)$. Perempuan mengonsumsi sayuran dan hasil olahannya, buah dan hasil olahannya serta bumbu dan olahannya lebih besar dari laki-laki. Berdasarkan golongan usia, subjek berusia 30-49 tahun mengonsumsi umbi-umbian dan hasil olahannya paling besar dibandingkan usia lainnya. Subjek berusia 50-64 tahun mengonsumsi kacang-kacangan dan biji, sayuran dan hasil olahannya, buah dan hasil olahannya, serta bumbu dan hasil olahannya paling besar dibandingkan golongan usia lainnya.

Subjek yang bertempat tinggal di perkotaan mengonsumsi kacang-kacangan dan biji, buah dan hasil olahannya, serta bumbu dan olahannya lebih besar dari subjek di perdesaan $(p<0,05)$. Sebaliknya, subjek di perdesaan mengonsumsi umbi-umbian dan hasil olahannya serta sayuran dan hasil olahannya lebih besar dari subjek perkotaan $(\mathrm{p}<0,05)$. Hasil ini sesuai dengan Laporan Susenas (Survei Sosial Ekonomi Nasional) 2014 yang menunjukkan bahwa pengeluaran subjek di perkotaan untuk kelompok pangan kacang-kacangan, buah-buahan, bumbu-bumbuan lebih besar dari subjek di perdesaan. Subjek di perdesaan memiliki rata-rata pengeluaran per kapita dalam sebulan untuk kelompok umbi-umbian dan sayur-sayuran, lebih besar dari subjek di perkotaan (BPS 2014).

Konsumsi pangan sumber pangan karotenoid di Indonesia masih rendah dan bervariasi antar subjek. Konsumsi pangan yang rendah akan 
Sefrina dkk.

Tabel 2. Konsumsi kelompok pangan sumber karotenoid berdasarkan karakteristik subjek

\begin{tabular}{|c|c|c|c|c|c|c|}
\hline \multirow{2}{*}{ Karakteristik } & \multirow{2}{*}{ Jumlah subjek } & \multicolumn{5}{|c|}{ Konsumsi kelompok pangan sumber karotenoid $\left(\mathrm{g} /\right.$ hari $^{1}{ }^{1}$} \\
\hline & & $\mathrm{Umbi}^{2}$ & Kacang $^{3}$ & Sayur ${ }^{4}$ & Buah $^{5}$ & Bumbu $^{6}$ \\
\hline Seluruh subjek & 86.036 & $31,4(0,0)$ & $47,9(0,0)$ & $71,8(55,9)$ & $36,8(0,0)$ & $15,4(10,3)$ \\
\hline \multicolumn{7}{|l|}{ Jenis kelamin } \\
\hline Laki-laki & 40.404 & $33,2(0,0)$ & $49,6(0,0)$ & $72,3(55,4)$ & $35,1(0,0)$ & $14,8(10,0)$ \\
\hline Perempuan & 45.632 & $29,8(0,0)^{\mathrm{b}}$ & $46,4(0,0)^{\mathrm{b}}$ & $71,3(56,0)$ & $38,4(0,0)^{\mathrm{b}}$ & $15,9(10,9)^{b}$ \\
\hline \multicolumn{7}{|l|}{ Golongan usia } \\
\hline 19-29 tahun & 14.698 & $27,8(0,0)$ & $44,0(0,0)$ & $64,9(49,0)$ & $31,1(0,0)$ & $14,4(9,5)$ \\
\hline $30-49$ tahun & 42.368 & $34,3(0,0)^{\mathrm{b}}$ & $46,6(0,0)^{\mathrm{a}}$ & $73,4(59,0)^{\mathrm{b}}$ & $38,1(0,0)^{\mathrm{b}}$ & $15,6(10,6)^{b}$ \\
\hline 50-64 tahun & 21.335 & $29,9(0,0)^{\mathrm{b}}$ & $51,9(0,0)^{\mathrm{b}}$ & $75,1(60,0)^{\mathrm{b}}$ & $40,0(0,0)^{\mathrm{b}}$ & $16,2(11,1)^{b}$ \\
\hline $65-80$ tahun & 6.842 & $26,9(0,0)^{b}$ & $51,6(0,0)^{\mathrm{b}}$ & $67,9(52,0)^{\mathrm{b}}$ & $32,8(0,0)^{\mathrm{b}}$ & $13,8(9,1)^{\mathrm{b}}$ \\
\hline$>80$ tahun & 793 & $17,9(0,0)^{\mathrm{b}}$ & $51,4(0,0)^{b}$ & $57,4(40,1)^{b}$ & $23,4(0,0)^{b}$ & $12,3(8,0)^{\mathrm{b}}$ \\
\hline \multicolumn{7}{|c|}{ Klasifikasi daerah } \\
\hline Perkotaan & 38.611 & $19,2(0,0)$ & $57,4(10,0)$ & $67,6(52,0)$ & $41,2(0,0)$ & $16,5(11,4)$ \\
\hline Perdesaan & 47.425 & $41,3(0,0)^{\mathrm{b}}$ & $40,1(0,0)^{\mathrm{b}}$ & $75,2(60,0)^{\mathrm{b}}$ & $33,3(0,0)^{\mathrm{b}}$ & $14,5(9,7)^{\mathrm{b}}$ \\
\hline \multicolumn{7}{|c|}{ Status pendidikan } \\
\hline Rendah & 59.364 & $35,4(0,0)$ & $48,3(0,0)$ & $71,8(56,0)$ & $32,3(0,0)$ & $14,6(10,0)$ \\
\hline Tinggi & 26.672 & $22,4(0,0)^{b}$ & $47,1(0,0)^{\mathrm{b}}$ & $71,6(55,6)$ & $46,9(0,0)^{\mathrm{b}}$ & $17,1(11,7)^{\mathrm{b}}$ \\
\hline \multicolumn{7}{|l|}{ Status pekerjaan } \\
\hline Tidak bekerja & 28.247 & $25,0(0,0)$ & $46,1(0,0)$ & $67,0(51,0)$ & $36,9(0,0)$ & $15,4(10,5)$ \\
\hline Bekerja & 57.789 & $34,5(0,0)^{\mathrm{a}}$ & $48,8(0,0)$ & $74,1(59,2)^{\mathrm{b}}$ & $36,8(0,0)^{\mathrm{b}}$ & $15,4(10,3)^{\mathrm{a}}$ \\
\hline
\end{tabular}

${ }^{1}$ Rata-rata (Median); ${ }^{2}$ Umbi-umbian dan hasil olahannya; ${ }^{3}$ Kacang-kacangan, biji; ${ }^{4}$ Sayuran dan hasil olahannya; ${ }^{5}$ Buah dan

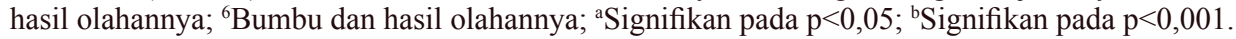

menimbulkan asupan zat gizi yang rendah pula. Menurut Nguyen et al. (2013), asupan zat gizi dapat dipengaruhi oleh beberapa faktor, salah satunya adalah konsumsi pangan. Faktor sosial, budaya, demografi dan gaya hidup dapat memengaruhi konsumsi pangan. Selain itu, pemilihan makanan sehat dapat dipengaruhi oleh beberapa aspek kandungan gizi, status kesehatan, suasana hati, dan harga (Puspadewi \& Briawan 2014).

\section{Asupan karotenoid}

Sebagian besar karotenoid termasuk larut lemak. Dalam tubuh manusia, golongan karoten ( $\alpha$-karoten, $\beta$-karoten, dan likopen) ditransportasi terutama bersama LDL, sedangkan xantofil (lutein dan zeaxantin) didistribusikan dalam jumlah sama antara HDL dan LDL pada serum darah (Maiani et al. 2009). Proses pencernaan dan absorpsi karotenoid diawali dari gerakan mekanik dan kimia yang menghasilkan pelepasan karotenoid dari food matrix, melalui proses dispersi ke dalam partikel emulsi lemak, kemudian larut dalam campuran bile salt micelle. Campuran ini bergerak melewati unstirred water layer yang dekat dengan mikrofili kemudian diserap oleh enterosit dan bergabung dengan lipoprotein lemak. Bioavailabilitas karotenoid pada manusia dipengaruhi oleh proses absorpsi dan metabolisme karotenoid, faktor genetik, status gizi, jenis kelamin, penuaan, dan infeksi subjek ( $\mathrm{Lu} \& \mathrm{Li}$ 2008; Fiedor et al. 2014).

Median asupan total karotenoid subjek sebesar 551,62 $\mu \mathrm{g} /$ hari (Tabel 3). Nilai asupan total karotenoid masyarakat Indonesia jauh lebih rendah dibandingkan dengan negara lain seperti di Bogor (rata-rata 7.578,40 $\mu \mathrm{g} /$ hari), Spanyol (median 5.274,50 $\mu \mathrm{g} /$ hari), dan USA (median $8.800 \mu \mathrm{g} /$ hari) (Puspita 2016; Agudo et al. 2007; Fitzgerald et al. 2013).

Tabel 3 menunjukkan median asupan total karotenoid pada kuartil rendah sebesar $240,38 \mu \mathrm{g} /$ hari dan pada kuartil tinggi sebesar 
Tabel 3. Asupan subkelas karotenoid dan karakteristik subjek menurut kuartil asupan total karotenoid

\begin{tabular}{|c|c|c|c|c|}
\hline \multirow[b]{2}{*}{ Variabel } & \multicolumn{3}{|c|}{ Asupan total karotenoid } & \multirow[b]{2}{*}{$p$-value } \\
\hline & $\begin{array}{c}\text { Kuartil rendah } \\
(\mathrm{n}=43.018)\end{array}$ & $\begin{array}{c}\text { Kuartil tinggi } \\
(\mathrm{n}=43.018)\end{array}$ & $\begin{array}{c}\text { Total } \\
(\mathrm{n}=86.036)\end{array}$ & \\
\hline \multicolumn{5}{|c|}{ Asupan karotenoid $(\mu \mathrm{g} / \mathrm{hari})$} \\
\hline Median total karotenoid & 240,38 & $1.544,62$ & 551,62 & \\
\hline \multicolumn{5}{|l|}{ Median subkelas karotenoid } \\
\hline$\alpha$-karoten & 1,13 & 9,39 & 1,57 & \\
\hline$\beta$-karoten & 8,71 & 417,38 & 14,95 & \\
\hline$\beta$-kriptoxantin & 80,40 & 29,17 & 75,60 & \\
\hline Lutein+zeaxantin & 6,01 & 166,78 & 14,71 & \\
\hline Likopen & 99,41 & 253,70 & 119,17 & \\
\hline \multicolumn{5}{|l|}{ Jenis kelamin ${ }^{1}$} \\
\hline Laki-laki $(\mathrm{n}=40.404)$ & 240,26 & $1.510,36$ & 519,74 & \\
\hline Perempuan $(\mathrm{n}=45.632)$ & 240,48 & $1.579,93$ & 579,52 & $0,000^{\mathrm{a}}$ \\
\hline \multicolumn{5}{|l|}{ Golongan usia ${ }^{1}$} \\
\hline $19-29$ tahun $(\mathrm{n}=14.698)$ & 239,27 & $1.507,87$ & 555,01 & \\
\hline $30-49$ tahun $(\mathrm{n}=42.368)$ & 244,13 & $1.544,44$ & 577,42 & \\
\hline 50-64tahun $(\mathrm{n}=21.335)$ & 239,40 & $1.611,18$ & 544,80 & \\
\hline $65-80$ tahun $(\mathrm{n}=6.842)$ & 216,42 & $1.474,83$ & 430,21 & \\
\hline$>80$ tahun $(\mathrm{n}=793)$ & 206,51 & $1.304,30$ & 383,19 & $0,000^{\mathrm{a}}$ \\
\hline \multicolumn{5}{|l|}{ Klasifikasi daerah $^{1}$} \\
\hline Perkotaan $(\mathrm{n}=38.611)$ & 243,67 & $2.639,58$ & $1.547,69$ & \\
\hline Perdesaan $(\mathrm{n}=47.425)$ & 239,88 & 922,25 & 332,29 & $0,000^{\mathrm{a}}$ \\
\hline \multicolumn{5}{|l|}{ Status pendidikan $^{1}$} \\
\hline Rendah $(\mathrm{n}=59.364)$ & 237,66 & $1.344,39$ & 443,17 & \\
\hline Tinggi $(\mathrm{n}=26.672)$ & 250,96 & $1.963,99$ & 893,95 & $0,000^{\mathrm{a}}$ \\
\hline \multicolumn{5}{|l|}{ Status pekerjaan ${ }^{1}$} \\
\hline Tidak bekerja $(\mathrm{n}=28.247)$ & 240,52 & $1.647,24$ & 606,52 & \\
\hline Bekerja $(\mathrm{n}=57.789)$ & 240,32 & $1.503,07$ & 525,35 & $0,000^{\mathrm{a}}$ \\
\hline
\end{tabular}

${ }^{1}$ Median asupan total karotenoid; ${ }^{a}$ Signifikan pada uji komparatif antara karakteristik subjek dengan asupan total karotenoid $(\mathrm{p}<0,05)$.

$1.544,62 \mu \mathrm{g} /$ hari. Berdasarkan asupan subkelas karotenoid, $\beta$-karoten merupakan subkelas dengan median tertinggi pada kuartil tinggi dan seluruh subjek. Median asupan $\beta$-karoten masyarakat Indonesia $(14,95 \mu \mathrm{g} / \mathrm{hari})$ lebih rendah diban-dingkan penelitian lain di Bogor sebesar 297,00 $\mu \mathrm{g} / \mathrm{hari}$ dan 4.074,20 $\mu \mathrm{g} / \mathrm{hari}$ serta di Spanyol sebesar 1678,60 $\mu \mathrm{g}$ /hari (De 1996; Puspita 2016; Agudo et al. 2007). Bahan pangan sumber $\beta$-karoten yang dikonsumsi subjek antara lain ubi jalar, bayam dan wortel. Sebuah penelitian case control di USA menunjukkan asupan $\beta$-karoten yang tinggi (median asupan $7.644 \mu \mathrm{g} /$ hari) mampu menurunkan $48 \%$ kanker kolorektal $(\mathrm{OR}=0,52 ; 95 \% \mathrm{CI}: 0,38-0,71)$ dengan $\mathrm{p}<0,01$ (Williams et al. 2010).

Asupan tertinggi pada kuartil rendah adalah likopen $(99,41 \mu \mathrm{g} / \mathrm{hari})$ dengan bahan pangan yang paling besar berkontribusi adalah tomat merah, bayam, pepaya, dan cabai rawit. Likopen penelitian ini lebih rendah dibandingkan penelitian di USA $(7.686 \pm 6.268 \mu \mathrm{g} / \mathrm{hari})$ yang juga menunjukkan likopen sebagai kontributor tertinggi pada asupan total karotenoid. Likopen merupakan karotenoid yang paling dominan berada dalam plasma darah manusia. Konsentrasi 
Sefrina dkk.

Tabel 4. Konsumsi kelompok pangan menurut kuartil asupan total karotenoid

\begin{tabular}{|c|c|c|c|c|}
\hline \multirow[b]{2}{*}{ Variabel } & \multicolumn{3}{|c|}{ Asupan total karotenoid } & \multirow[b]{2}{*}{ p-value } \\
\hline & $\begin{array}{c}\text { Kuartil rendah } \\
(\mathrm{n}=43.018)\end{array}$ & $\begin{array}{c}\text { Kuartil tinggi } \\
(\mathrm{n}=43.018)\end{array}$ & $\begin{array}{c}\text { Total } \\
(\mathrm{n}=86.036)\end{array}$ & \\
\hline \multicolumn{5}{|c|}{ Konsumsi sumber karotenoid (g/hari) ${ }^{1}$} \\
\hline \multicolumn{5}{|l|}{ Kelompok pangan } \\
\hline Umbi-umbian dan hasil olahannya & $32,1(0,0)$ & $30,7(0,0)$ & $31,40(0,00)$ & $0,000^{\mathrm{a}}$ \\
\hline Kacang-kacangan, biji & $5,3(0,0)$ & $90,5(62,7)$ & $47,88(0,00)$ & $0,000^{\mathrm{a}}$ \\
\hline Sayur dan hasil olahannya & $57,4(44,0)$ & $86,1(67,5)$ & $71,75(55,9)$ & $0,000^{\mathrm{a}}$ \\
\hline Buah dan hasil olahannya & $21,8(0,0)$ & $51,9(0,0)$ & $36,83(0,00)$ & $0,000^{\mathrm{a}}$ \\
\hline Bumbu dan olahannya & $10,9(8,0)$ & $19,9(13,8)$ & $15,39(10,30)$ & $0,000^{\mathrm{a}}$ \\
\hline
\end{tabular}

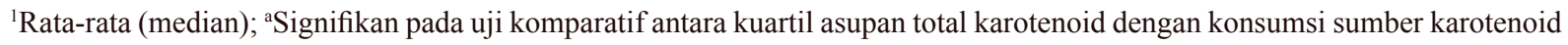
$(\mathrm{p}<0,05)$

likopen yang tinggi dalam darah berhubungan dengan penurunan risiko penyakit kanker, neoplasia dan infark miokard (Sahni et al. 2009).

Berdasarkan jenis kelamin, asupan total karotenoid pada perempuan lebih besar dari lakilaki $(\mathrm{p}<0,05)$. Perbedaan ini dapat dipengaruhi konsumsi sumber karotenoid lebih besar pada perempuan daripada laki-laki $(\mathrm{p}<0,05)$. Hasil ini sesuai dengan penelitian Park et al. (2009) yang menunjukkan asupan total karotenoid lebih besar pada perempuan $(7.110 \pm 4.323 \mu \mathrm{g} / \mathrm{hari})$ daripada laki-laki (5.483 $\pm 3.373 \mu \mathrm{g} /$ hari). Berdasarkan golongan usia, subjek berusia 30-49 tahun memiliki asupan total karotenoid tertinggi $(577,42$ $\mu \mathrm{g} /$ hari). Subjek pada golongan usia ini memiliki nilai konsumsi umbi-umbian dan hasil olahannya tertinggi, tertinggi ke-2 pada konsumsi sayuran dan hasil olahannya, buah dan hasil olahannya, serta bumbu dan hasil olahannya dibandingkan usia lainnya. Asupan total karotenoid pada subjek berusia $>64$ tahun cenderung lebih rendah dapat dipengaruhi oleh menurunnya kemampuan fisiologi (Helmizar et al. 2010). Subjek yang tinggal di perkotaan memiliki asupan lima kali lipat lebih besar dari perdesaan $(\mathrm{p}<0,05)$. Perbedaan tersebut dapat dipengaruhi oleh konsumsi buah dan hasil olahannya, kacang-kacangan dan biji, serta bumbu dan hasil olahannya yang lebih besar pada subjek perkotaan daripada perdesaan. Asupan total karotenoid lebih besar pada subjek berpendidikan tinggi dan tidak bekerja $(\mathrm{p}<0,05)$.

Tabel 4 menunjukkan terdapat perbedaan yang signifikan jumlah konsumsi kelompok pangan sumber karotenoid berdasarkan kuartil asupan total karotenoid. Konsumsi kelompok pangan sumber karotenoid cenderung lebih be- sar pada kuartil tinggi asupan total karotenoid, kecuali pada kelompok pangan umbi-umbian dan hasil olahan.

Kecenderungan nilai asupan karotenoid yang lebih rendah dibandingkan penelitian sebelumnya termasuk di negara lain dapat dipengaruhi oleh beberapa faktor yaitu (1) terbatasnya DKBM Indonesia sehingga terdapat beberapa bahan pangan yang dikonsumsi subjek belum diketahui kandungan karotenoid-nya; (2) SKMI 2014 tidak memiliki tujuan khusus untuk menilai asupan karotenoid; (3) kelemahan dari food recall 1x24 jam adalah jenis dan jumlah bahan pangan mungkin belum tercakup selama 24 jam sebelum wawancara. Penelitian ini merupakan langkah awal dalam rangka menghasilkan data baseline asupan karotenoid pada usia dewasa di Indonesia.

\section{KESIMPULAN}

Rata-rata konsumsi kelompok pangan yang menjadi kontributor dalam asupan karotenoid adalah sayuran dan hasil olahannya 71,8 g/hari, bumbu dan hasil olahannya $15,4 \mathrm{~g} /$ hari, buah dan hasil olahannya $36,8 \mathrm{~g} /$ hari, umbi-umbian dan hasil olahannya 31,4 g/hari, kacang-kacangan dan biji 47,9 g/hari. Median asupan total karotenoid subjek adalah 551,62 $\mu \mathrm{g} /$ hari. Terdapat perbedaan yang signifikan antara asupan total karotenoid berdasarkan karakteristik subjek (jenis kelamin, golongan usia, klasifikasi daerah, status pendidikan, status pekerjaan) dan konsumsi kelompok pangan sumber karotenoid. Saran untuk penelitian selanjutnya antara lain menganalisis kandungan bahan pangan Indonesia yang belum 
diketahui, mengestimasi asupan karotenoid berdasarkan instrumen survei konsumsi makanan yang mencerminkan kebiasaan masyarakat Indonesia seperti food frequency questionnare.

\section{UCAPAN TERIMA KASIH}

Penulis mengucapkan terima kasih kepada Laboratorium Manajemen Data, Badan Penelitian dan Pengembangan Kesehatan Kementerian Kesehatan Republik Indonesia yang telah berkenan memberikan data SKMI 2014 dan tim Riset SKMI 2014 yang telah melakukan pengambilan data di seluruh provinsi di Indonesia.

\section{DAFTAR PUSTAKA}

Agudo A, Cabrera, Amiano P, Ardana E, Barricarte A, Berengeur T, Chirlaque MD, Dorronsoro $\mathrm{M}$, Jakszyn $\mathrm{P}$, Larranaga $\mathrm{N}$, et al. 2007. Fruit and vegetable intakes, dietary antioxidant nutrients, and total mortality in spanish adults: findings from the spanish cohort of the European Prospective Investigation into Cancer and Nutrition (EPICSpain). Am J Clin Nutr 85(6):1634-1642.

[Balitbangkes] Badan Penelitian dan Pengembangan Kesehatan. 2013. Riset Kesehatan Dasar 2013. Jakarta: Balitbangkes Kementerian Kesehatan RI.

[Balitbangkes] Badan Penelitian dan Pengembangan Kesehatan. 2014. Buku Studi Diet Total: Survei Konsumsi Makanan Individu Indonesia 2014. Jakarta: Balitbangkes Kementerian Kesehatan RI.

Boeing H, Bechthold A, Bub A, Ellinger S, Haller D, Kroke A, Leschik-Bonnet E, Muller MJ, Oberritter H, Schulze M, et al. 2012. Critical review: vegetables and fruit in the prevention of chronic diseases. Eur J Nutr 51(6):637-663.

[BPS] Badan Pusat Statistik. 2014. Pengeluaran untuk Konsumsi Penduduk Indonesia 2014 Berdasarkan Hasil Susenas Maret 2014. Jakarta: BPS.

De P. 1996. Food-based approaches for controlling vitamin A deficiency: studies in breastfeeding women in Indonesia [tesis]. Belanda: Wageningen.

Fiedor J, Burda K. 2014. Potential role of carotenoids as antioxidants in human health and disease. Nutrients 6(2):466-488.
Fitzgerald KC, O'Reilly E, Fondell E, Falcone GJ, Mc Cullough ML, Park Y, Kolonel LN, Ascherio A. 2013. Intakes of vitamin $\mathrm{C}$ and carotenoids and risk of amyotrophic lateral sclerosis: pooled results from 5 cohort studies. Ann Neurol 73(2):236-245.

Helmizar, Jalal F, Liputo I. 2010. Antioksidan dalam masakan Minang dan potensi protektif terhadap risiko penyakit kardiovaskular. Jurnal Kesehatan Masyarakat 4(1):13-20.

Holick CN, Michaud DS, Stolzanberg-solomon R, Mayne ST, Pietinen P, Taylor PR, Vrtamo J, Albanes D. 2002. Dietary carotenoids, serum $\beta$-carotene, and retinol and risk of lung cancer in the alpha-tocopherol, beta-carotene cohort study. American Journal of Epidemiology 156(6): 536-547.

Lu S, Li L. 2008. Carotenoid metabolism: biosynthesis, regulation, and beyond. J Integr Plant Biol 50(7):778-785.

Maiani G, Caston MJP, Catasta G, Toti E, Cambrodon IG, Bysted A, Granado-Lorencio F, Olmedilla-Alonso B, Knuthsen P, Valoti M, et al. 2009. Carotenoids: actual knowledge on food sources, intakes, stability and bioavailability and their protective role in humans. Mol Nutr Food Res 53(S2):1-25.

Nguyen PH, Strizich G, Lowe A, Nguyen H, Pham H, Truong T, Nguyen S, Martorell R, Ramakrishnan U. 2013. Food consumption patterns and associated factors among Vietnamese women of reproductive age. Nutr J 12(1):126.

Park SY, Nomura AMY, Murphy SP, Wilkens LR, Henderson BE, Kolonel LN. 2009. Carotenoid intake and colorectal cancer risk: The Multiethnic Cohort Study. J Epidemiol 19(2):63-71.

Pham-Huy LA, He H, Pham-Huye C. 2008. Free radicals, antioxidants in disease and health. Int J of Biomedical Science 4 (2):89-96.

Puspadewi RH, Briawan D. 2014. Persepsi tentang pangan sehat, alasan pemilihan pangan dan kebiasaan makan sehat pada mahasiswa. J Gizi Pangan 9(3):211-218.

Puspita NC. 2016. Estimasi asupan flavonoid dan karotenoid melalui survey konsumsi pangan dengan metode Food Frequency Questionnaire pada masyarakat Bogor [skripsi]. Bogor: Institut Pertanian Bogor. 
Sefrina dkk.

Sahni S, Hannan MT, Blumberg J, Cupples LA, Kiel DP, Tucker KL. 2009. Protective effect of total carotenoid and lycopene Intake on the risk of hip fracture: A 17-year follow-up from the framingham osteoporosis study. J Bone Miner Res 24 (6):10861094.

Sluijs I, Cadier E, Beulens JWJ, Spijkerman AMW, van der Schouw YT. 2015. Dietary intake of carotenoids and risk of type 2 diabetes. Nutr Metab Cardiovasc Dis 25(4):376-381.
[USDA] United States Department of Agriculture. 2015. USDA National Nutrient Database for Standard Reference Release 28. Maryland: USDA.

[WHO] World Health Organization. 2014. Global Status Report on Noncommunicable Disease 2014. Geneva: WHO Press.

Williams CD, Satia JA, Adair LS, Stevens J, Galanko J, Keku TO, Sandler. 2010. Antioxidant and DNA methylation-related nut-rients and risk of distal colorectal cancer. Cancer Causes \& Control 21(8):11711181 . 